\title{
A vibrational spectroscopic study of the phosphate mineral vantasselite $\mathrm{Al}_{4}\left(\mathrm{PO}_{4}\right)_{3}(\mathrm{OH})_{3} \cdot 9 \mathrm{H}_{2} \mathrm{O}$
}

\author{
Ray L. Frost ${ }^{\mathrm{a}, *}$, Ricardo Scholz ${ }^{\mathrm{b}}$, Fernanda Maria Belotti ${ }^{\mathrm{c}}$, Andrés López ${ }^{\mathrm{a}}$, Frederick L. Theiss ${ }^{\mathrm{a}}$

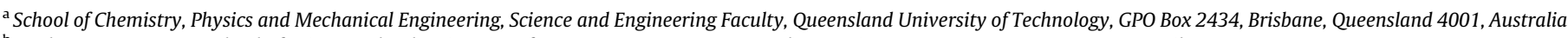 \\ ${ }^{\mathrm{b}}$ Geology Department, School of Mines, Federal University of Ouro Preto, Campus Morro do Cruzeiro, Ouro Preto, MG 35,400-00, Brazil \\ ' Federal University of Itajubá, Campus Itabira, Itabira, MG 35,903-087, Brazil
}

\section{H I G H L I G H T S}

- We have studied the phosphate mineral vantasselite $\mathrm{Al}_{2}\left(\mathrm{PO}_{4}\right)(\mathrm{OH})_{3} \cdot 3 \mathrm{H}_{2} \mathrm{O}$.

- Using a combination of SEM with EDX and Raman and infrared spectroscopy.

- Chemical analysis shows a mineral containing $\mathrm{Al}$, Fe and $\mathrm{P}$.

- A comparison is made with other aluminum containing phosphate minerals.

- Vibrational spectroscopy offers a mechanism for the study of the molecular structure of vantasselite.

\section{A R T I C L E I N F O}

\section{Article history:}

Received 28 October 2014

Received in revised form 15 January 2015

Accepted 23 March 2015

Available online 28 March 2015

\section{Keywords:}

Vantasselite

Phosphate

SEM

EDS

Raman spectroscopy

Infrared spectroscopy
G R A P H I C A L A B S T R A C T

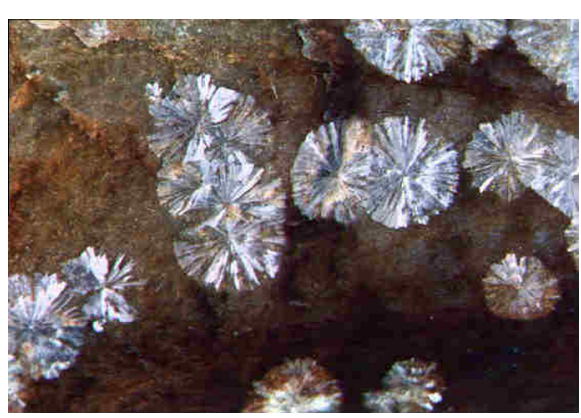

\begin{abstract}
A B S T R A C T
We have studied the phosphate mineral vantasselite $\mathrm{Al}_{4}\left(\mathrm{PO}_{4}\right)_{3}(\mathrm{OH})_{3} \cdot 9 \mathrm{H}_{2} \mathrm{O}$ using a combination of SEM with EDX and Raman and infrared spectroscopy. Qualitative chemical analysis shows $\mathrm{Al}$, Fe and $\mathrm{P}$. Raman bands at 1013 and $1027 \mathrm{~cm}^{-1}$ are assigned to the $\mathrm{PO}_{4}^{3-} v_{1}$ symmetric stretching mode. The observation of two bands suggests the non-equivalence of the phosphate units in the vantasselite structure. Raman bands at 1051,1076 and $1090 \mathrm{~cm}^{-1}$ are attributed to the $\mathrm{PO}_{4}^{3-} v_{3}$ antisymmetric stretching vibration. A comparison is made with the spectroscopy of wardite. Strong infrared bands at 1044, 1078, 1092, $1112,1133,1180$ and $1210 \mathrm{~cm}^{-1}$ are attributed to the $\mathrm{PO}_{4}^{3-} v_{3}$ antisymmetric stretching mode. Some of these bands may be due to $\delta \mathrm{Al}_{2} \mathrm{OH}$ deformation modes. Vibrational spectroscopy offers a mechanism for the study of the molecular structure of vantasselite.
\end{abstract}

(c) 2015 Elsevier B.V. All rights reserved.

\section{Introduction}

Vantasselite is a rare aluminum phosphate mineral with chemical formula given as $\mathrm{Al}_{4}\left(\mathrm{PO}_{4}\right)_{3}(\mathrm{OH})_{3} \cdot 9 \mathrm{H}_{2} \mathrm{O}$. The mineral crystalizes with orthorhombic symmetry, Point Group: 222, unit cell parameters are: Space Group: Pmam, Pma2 or P2 ${ }_{1} a m ; a=10.528(4)$,

\footnotetext{
* Corresponding author. Tel.: +61 73138 2407; fax: +61 731381804 . E-mail address: r.frost@qut.edu.au (R.L. Frost).
}

$b=16.541(3), c=20.373(6)$ and $Z=8$. The crystals occur with lamellar habitus, elongated along 100 . The crystal aggregates forms rosettes up to $5 \mathrm{~mm}$. Vantasselite was first described from Bihain, Vielsalm, Stavelot Massif, Belgium [1]. The mineral occurs on dumps in a quartzite quarry in quartz veinlets or lining schistosity planes. The associated minerals are wavellite, cacoxenite, variscite, turquoise, lithiophorite, cryptomelane, quartz, clinochlore and muscovite. There is no crystal structure determination for vantasselite. The only scientific publication about this mineral is the 
original description [1]. Due to the cleavage and the type of fragment like plates, the unit cell refinement is not useful, or is very complicated to be used for the determination of the crystal structure. Thus, it seems appropriate in order to determine aspects of the molecular structure of vantasselite to use vibrational spectroscopic techniques.

Interestingly Farmer in his book on the infrared spectra of minerals divided the vibrational spectra of phosphates according to the presence, or absence of water and hydroxyl units in the minerals [2]. In aqueous systems, Raman spectra of phosphate oxyanions show a symmetric stretching mode $\left(v_{1}\right)$ at $938 \mathrm{~cm}^{-1}$, the antisymmetric stretching mode $\left(v_{3}\right)$ at $1017 \mathrm{~cm}^{-1}$, the symmetric bending mode $\left(v_{2}\right)$ at $420 \mathrm{~cm}^{-1}$ and the $v_{4}$ mode at $567 \mathrm{~cm}^{-1}$ [3-5]. Farmer reported the infrared spectra of berlinite $\left(\mathrm{AlPO}_{4}\right)$ with $\mathrm{PO}_{4}$ stretching modes at $1263,1171,1130$ and $1114 \mathrm{~cm}^{-1}$; bending modes at 511, 480, 451, 379 and $605 \mathrm{~cm}^{-1}$. $\mathrm{Al}-\mathrm{O}$ modes were found at 750, 705, 698 and $648 \mathrm{~cm}^{-1}$. On hydration of the mineral as with variscite $\left(\mathrm{AlPO}_{4} \cdot 2 \mathrm{H}_{2} \mathrm{O}\right), \mathrm{PO}_{4}$ stretching modes were found at 1160,1075, 1050 and $938 \mathrm{~cm}^{-1}$; bending modes at 515,450 and $420 \mathrm{~cm}^{-1}$; in addition $\mathrm{H}_{2} \mathrm{O}$ stretching bands were found at $3588,3110,2945 \mathrm{~cm}^{-1}$. For the mineral augelite $\left(\mathrm{AlPO}_{4}(\mathrm{OH})_{3}\right)$, infrared bands were observed at $930\left(v_{1}\right), 438\left(v_{2}\right)$, $1205,1155,1079,1015\left(v_{3}\right)$ and $615,556 \mathrm{~cm}^{-1}\left(v_{4}\right)$. For augelite, $\mathrm{OH}$ stretching modes were not observed.

There are a couple of minerals the chemistry of which may be compared with vantasselite. These include wardite and cyrilovite. There have been some studies of the vibrational spectroscopy of wardite [6,7]. Tarte et al. collected the infrared spectra of five samples of cyrilovite $\mathrm{NaFe}_{3}\left(\mathrm{PO}_{4}\right)_{2}(\mathrm{OH})_{4} \cdot 2\left(\mathrm{H}_{2} \mathrm{O}\right)$ [8] and wardite [7]. Cyrilovite is analogous to wardite, with ferric iron replacing the aluminum in the structure. It is likely that solid solutions of the two minerals are formed with varying amounts of ferric ion and aluminum in the structure. The mineral wardite is capable of crystallizing in a similar form to that of cyrilovite because of their closely related chemical compositions. Between wardite's composition, $\mathrm{NaAl}_{3}\left(\mathrm{PO}_{4}\right)_{2}(\mathrm{OH})_{4} \cdot 2\left(\mathrm{H}_{2} \mathrm{O}\right)$, and cyrilovite composition, $\mathrm{NaFe}_{3}\left(\mathrm{PO}_{4}\right)_{2}(\mathrm{OH})_{4} \cdot 2\left(\mathrm{H}_{2} \mathrm{O}\right)$, these minerals are able to form end members of a series of solid solutions. Either of the two minerals can occur in various proportions in a series of solid solutions in the wardite mineral group. Cyrilovite is a rare accessory mineral in some oxidizing phosphate-bearing granite pegmatites and iron deposits. The vibrational spectrum is dependent upon the ratio of the $\mathrm{Al} / \mathrm{Fe}$. Tarte et al. found that the two minerals wardite and cyrilovite can be distinguished by the spectral patterns of the $\mathrm{OH}$ stretching region in the infrared spectrum [7]. These workers did

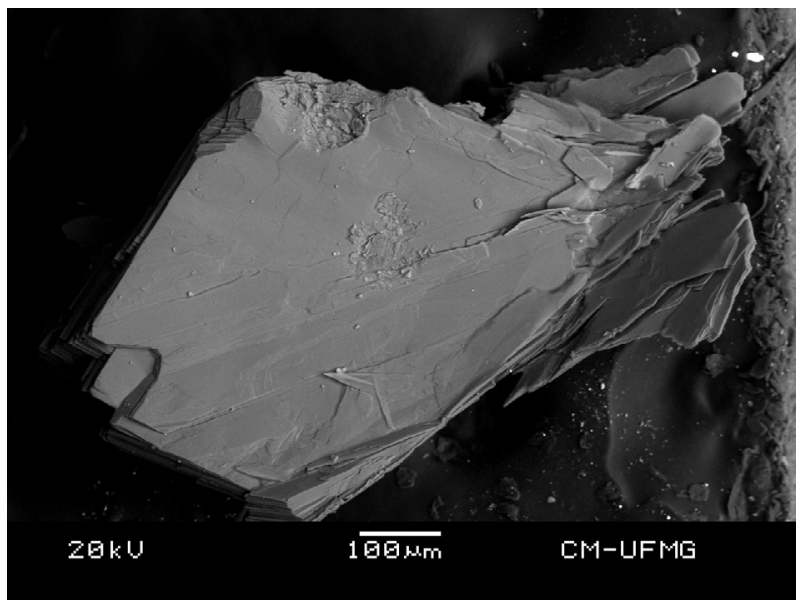

Fig. 1. Backscattered electron image (BSI) of a vantasselite fragment up to $0.5 \mathrm{~mm}$ in length. not interpret the spectra of the phosphate because of complexity and no detailed assignments were given. Breitinger et al. reported the combined vibrational spectra of a natural wardite. Breitinger et al. used a full array of techniques including inelastic neutron scattering, infrared, Raman and near infrared techniques [6]. These workers used a natural wardite with significant amounts of ferric iron in the structure. In other words, the sample analyzed was fundamentally a solid solution of wardite and cyrilovite, but at the wardite end. The original papers on the infrared spectrum of isolated phosphate units was published by Lazarev [9]. Of course, phosphates structures are different. Usually they have rather low symmetry: orthorhombic, monoclinic, or even triclinic [10]. Farmer based upon the work of Petrov et al. [11-13] made a comparison of the results of the vibrational spectrum of a series of phosphates.

Raman spectroscopy has proven most useful for the study of mineral structures [14-19]. The objective of this research is to report the Raman and infrared spectra of vantasselite and to relate the spectra to the molecular structure of the minerals. The mineral vantasselite may be described as an environmental mineral in that it is formed in waste dumps and mining wastes, as such the mineral is often small in crystal size and difficult to measure by Xray diffraction. The number of vantasselite occurrences is limited [20]. This is the first report of a systematic vibrational spectroscopic study of vantasselite from Belgium.

\section{Experimental}

\section{Mineral}

The vantasselite sample studied in this work was collected from the Bihain, Vielsalm, Stavelot Massif, Luxembourg Province, Belgium. The sample is incorporated into the collection of the Geology Department of the Federal University of Ouro Preto, Minas Gerais, Brazil, with sample code SAC-085. The sample was gently crushed and the associated minerals were removed under a stereomicroscope Zeiss Stemi DV4 from the Museu de Ciência e Técnica of the Federal University of Ouro Preto. Scanning electron microscopy (SEM) was applied to support the mineral characterization.

\section{Scanning electron microscopy (SEM)}

Experiments and analyses involving electron microscopy were performed in the Center of Microscopy of the Universidade Federal de Minas Gerais, Belo Horizonte, Minas Gerais, Brazil (http://www.microscopia.ufmg.br).

A vantasselite crystal aggregate up to $0.5 \mathrm{~mm}$ was coated with a $5 \mathrm{~nm}$ layer of evaporated carbon. Backscattering Electron images was obtained using a JEOL JSM-6360LV equipment. Qualitative and semi-quantitative chemical analyses in the EDS mode were performed with a ThermoNORAN spectrometer model Quest and were applied to support the mineral characterization.

\section{Raman spectroscopy}

Crystals of vantasselite were placed on a polished metal surface on the stage of an Olympus BHSM microscope, which is equipped with $10 \times, 20 \times$, and $50 \times$ objectives. The microscope is part of a Renishaw 1000 Raman microscope system, which also includes a monochromator, a filter system and a CCD detector (1024 pixels). The Raman spectra were excited by a Spectra-Physics model 127 He-Ne laser producing highly polarized light at $633 \mathrm{~nm}$ and collected at a nominal resolution of $2 \mathrm{~cm}^{-1}$ and a precision of $\pm 1 \mathrm{~cm}^{-1}$ in the range between 100 and $4000 \mathrm{~cm}^{-1}$. Repeated 


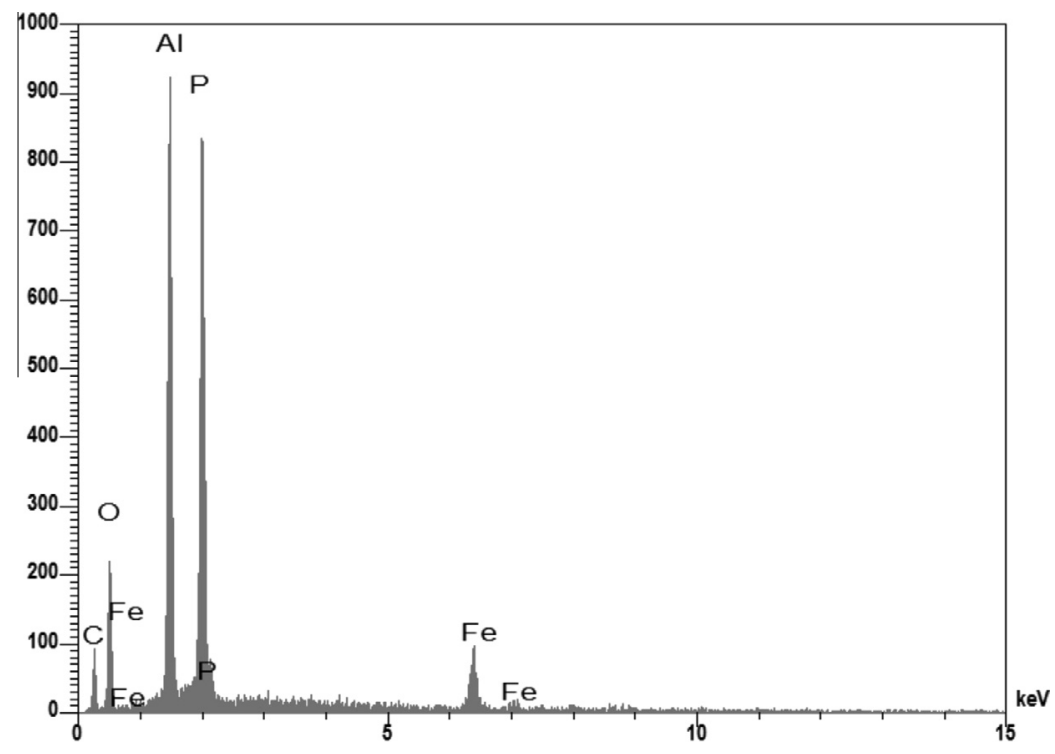

Fig. 2. EDS spectra of vantasselite.
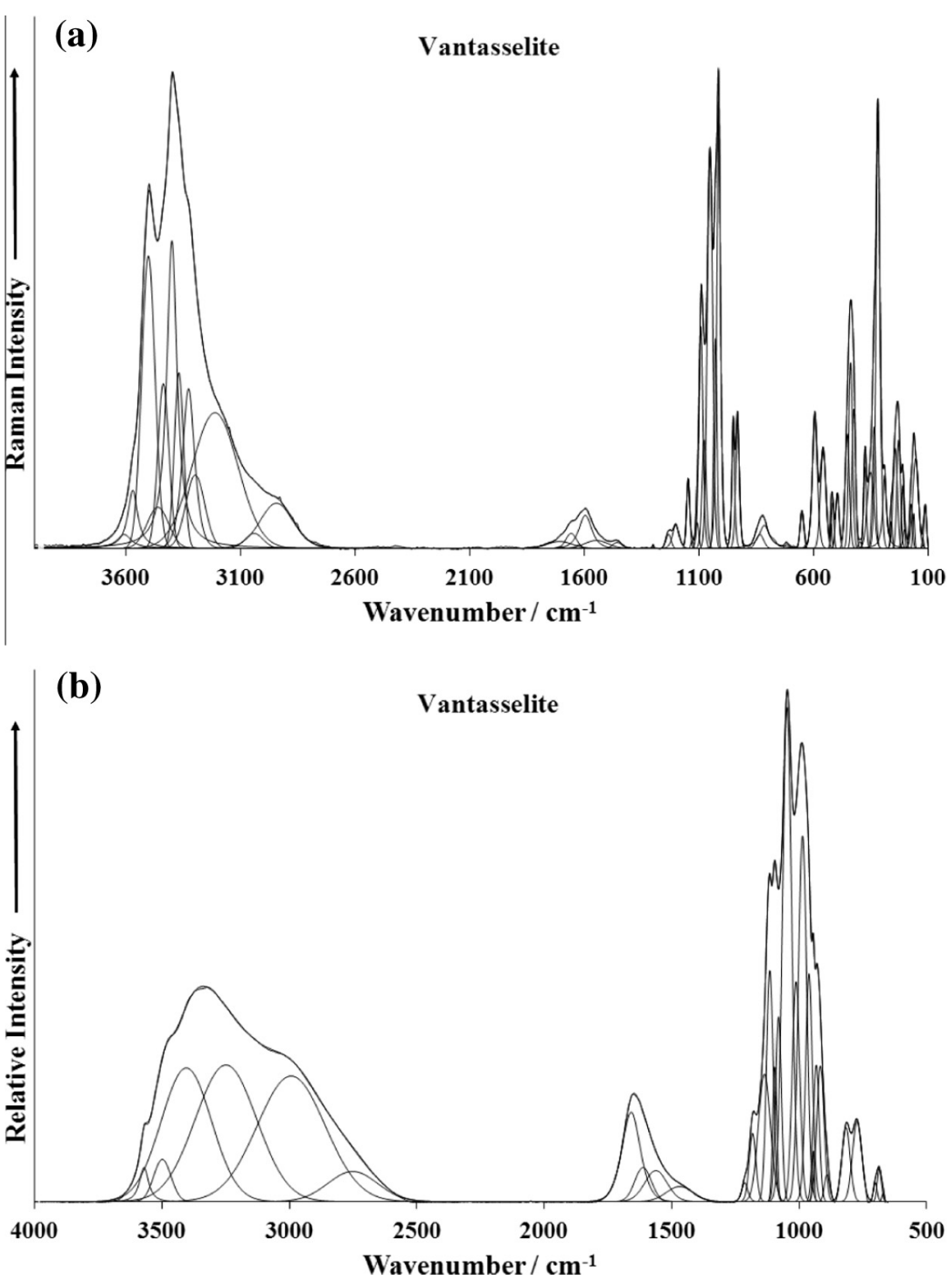

Fig. 3. (a) Raman spectrum of vantasselite over the $100-4000 \mathrm{~cm}^{-1}$ spectral range. (b) Infrared spectrum of vantasselite over the $500-4000 \mathrm{~cm}-1$ spectral range. 

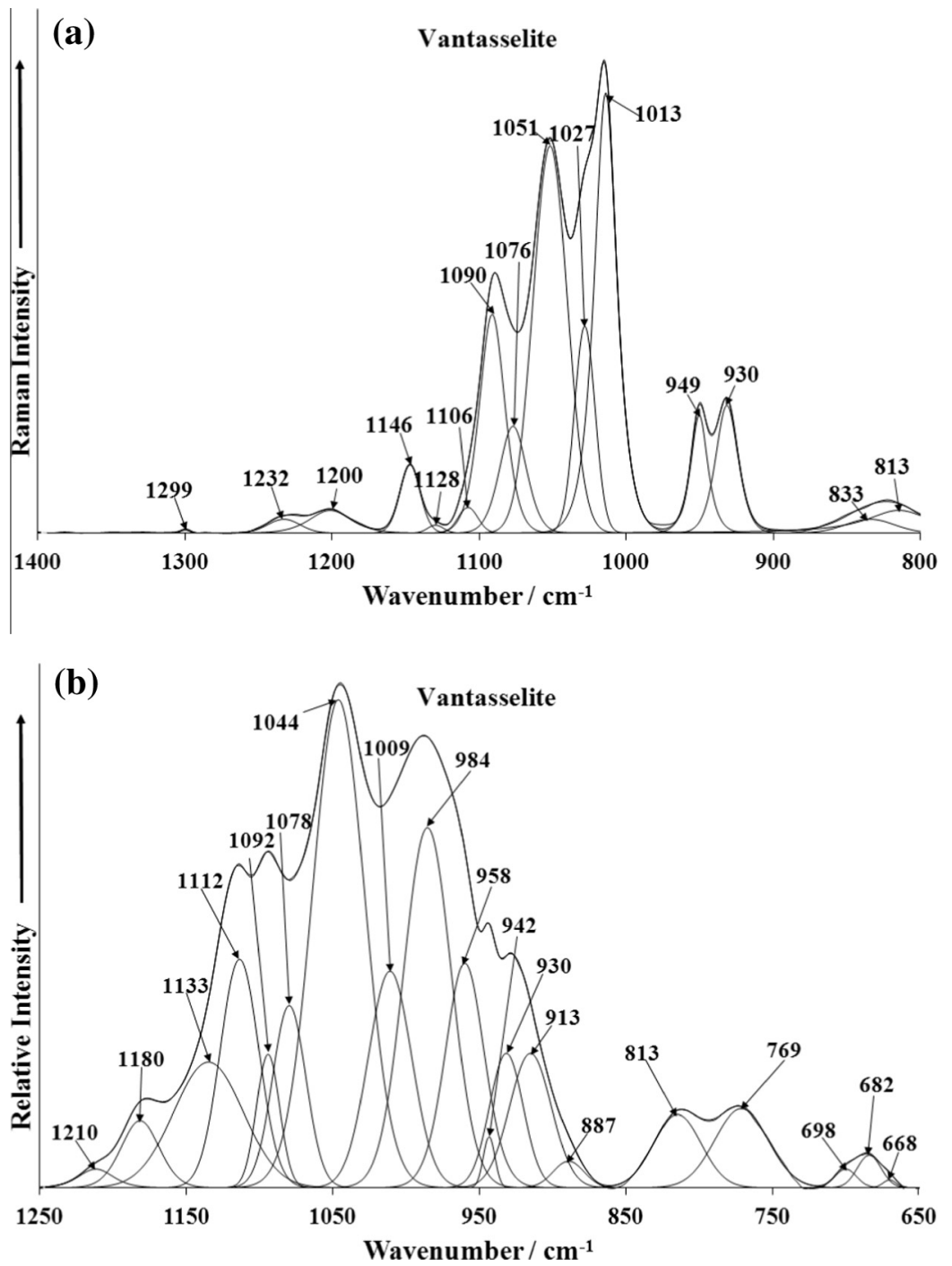

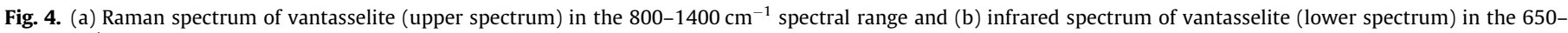
$1250 \mathrm{~cm}^{-1}$ spectral range.

acquisition on the crystals using the highest magnification $(50 \times)$ was accumulated to improve the signal to noise ratio in the spectra. Spectra were calibrated using the $520.5 \mathrm{~cm}^{-1}$ line of a silicon wafer.

A Raman spectrum of vantasselite is given in the RRUFF data base (http://rruff.info/Vantasselite). This spectrum is provided in supplementary information as Fig. S1. No assignment of the bands is given and the high wavenumber part of the vantasselite spectrum was not recorded.

\section{Infrared spectroscopy}

Infrared spectra were obtained using a Nicolet Nexus 870 FTIR spectrometer with a smart endurance single bounce diamond ATR cell. Spectra over the $4000-525 \mathrm{~cm}^{-1}$ range were obtained by the co-addition of 128 scans with a resolution of $4 \mathrm{~cm}^{-1}$ and a mirror velocity of $0.6329 \mathrm{~cm} / \mathrm{s}$. Spectra were co-added to improve the signal to noise ratio.

Band component analysis was undertaken using the Jandel 'Peakfit' (Erkrath, Germany) software package which enabled the type of fitting function to be selected and allowed specific parameters to be fixed or varied accordingly. Band fitting was done using a Lorentz-Gauss cross-product function with the minimum number of component bands used for the fitting process. The LorentzGauss ratio was maintained at values greater than 0.7 and fitting was undertaken until reproducible results were obtained with squared correlations $\left(r^{2}\right)$ greater than 0.995. Band fitting is undertaken with the minimum number of fitted bands. Band fitting of the spectra is quite reliable providing there is some band separation or changes in the spectral profile.

\section{Results and discussion}

\section{Chemical characterization}

The SEM image of vantasselite sample studied in this work is shown in Fig. 1. Vantasselite crystal aggregates show tabular habitus. A perfect cleavage on (001) is observed. Qualitative chemical analysis shows $\mathrm{Al}, \mathrm{Fe}$ and $\mathrm{P}$ (Fig. 2). The presence of $\mathrm{C}$ in the EDS spectra is due to the influence of carbon tape and coating.

\section{Vibrational spectroscopic background}

Farmer [2] divided the vibrational spectra of phosphates according to the presence, or absence of water and/or hydroxyl units in the minerals. In aqueous systems, Raman spectra of 
(a)

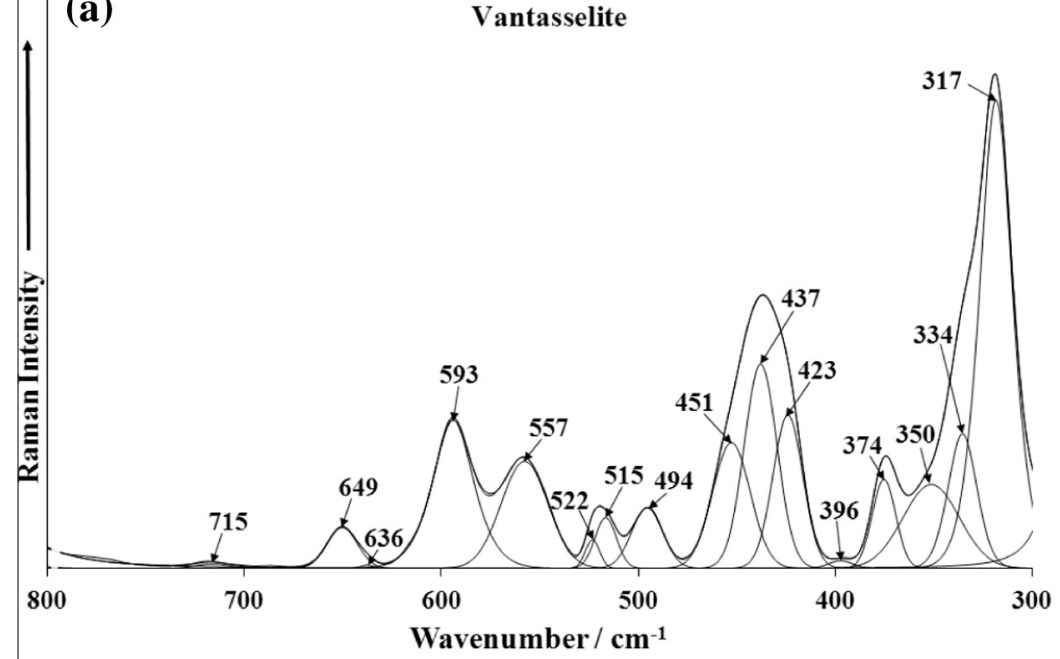

(b)

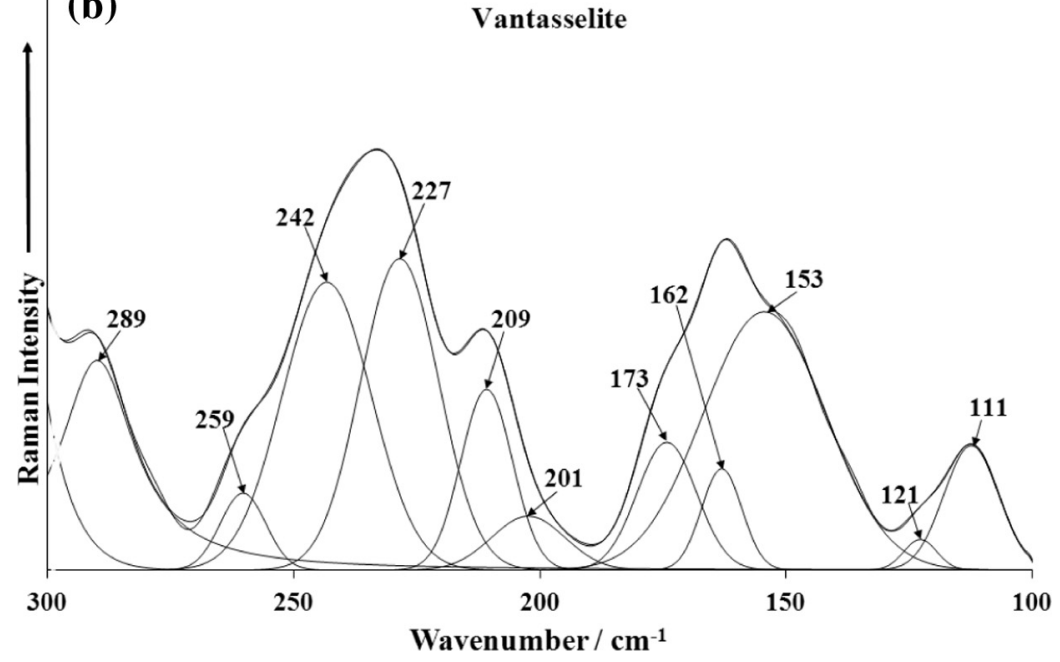

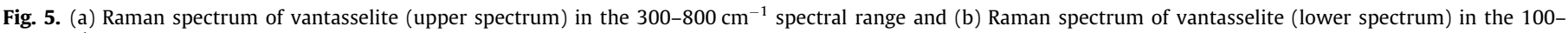
$300 \mathrm{~cm}^{-1}$ spectral range.

phosphate oxyanions show a symmetric stretching mode $\left(v_{1}\right)$ at $938 \mathrm{~cm}^{-1}$, the antisymmetric stretching mode $\left(v_{3}\right)$ at $1017 \mathrm{~cm}^{-1}$, the symmetric bending mode $\left(v_{2}\right)$ at $420 \mathrm{~cm}^{-1}$ and the $\left(v_{4}\right)$ mode at $567 \mathrm{~cm}^{-1}[3-5,21]$. The value for the $v_{1}$ symmetric stretching vibration of $\mathrm{PO}_{4}$ units as determined by infrared spectroscopy was given as $930 \mathrm{~cm}^{-1}$ (augelite), $940 \mathrm{~cm}^{-1}$ (wavellite), $970 \mathrm{~cm}^{-1}$ (rockbridgeite), $995 \mathrm{~cm}^{-1}$ (dufrénite) and $965 \mathrm{~cm}^{-1}$ (beraunite). The position of the symmetric stretching vibration is mineral dependent and a function of the cation and crystal structure. The fact that the symmetric stretching mode is observed in the infrared spectrum affirms a reduction in symmetry of the $\mathrm{PO}_{4}$ units.

The value for the $v_{2}$ symmetric bending vibration of $\mathrm{PO}_{4}$ units as determined by infrared spectroscopy was given as $438 \mathrm{~cm}^{-1}$ (augelite), $452 \mathrm{~cm}^{-1}$ (wavellite), 440 and $415 \mathrm{~cm}^{-1}$ (rockbridgeite), 455 , 435 and $415 \mathrm{~cm}^{-1}$ (dufrénite) and 470 and $450 \mathrm{~cm}^{-1}$ (beraunite). The observation of multiple bending modes provides an indication of symmetry reduction of the $\mathrm{PO}_{4}$ units. This symmetry reduction is also observed through the $v_{3}$ antisymmetric stretching vibrations. Augelite shows infrared bands at 1205, 1155, 1079 and $1015 \mathrm{~cm}^{-1}$ [22,23]; wavellite at $1145,1102,1062$ and $1025 \mathrm{~cm}^{-1}$; rockbridgeite at 1145,1060 and $1030 \mathrm{~cm}^{-1}$; dufrénite at 1135,1070 and $1032 \mathrm{~cm}^{-1}$; and beraunite at 1150, 1100, 1076 and $1035 \mathrm{~cm}^{-1}$.

\section{Vibrational spectroscopy}

The Raman spectrum of vantasselite in the $100-4000 \mathrm{~cm}^{-1}$ spectral range is displayed in Fig. 3a. This spectrum shows the position and relative intensities of the Raman bands. It is noted that there are large parts of the spectrum where no intensity or minimal intensity is observed. Thus, the spectrum is subdivided into subsections depending upon the type of vibration being studied. The infrared spectrum of vantasselite in the $500-4000 \mathrm{~cm}^{-1}$ spectral region is reported in Fig. $3 \mathrm{~b}$. This figure shows the position of the infrared bands and their relative intensities. As for the Raman spectrum, there are parts of the spectrum where little or no intensity is observed; thus the spectrum is subdivided into sections based upon the type of vibration being analyzed.

The Raman spectrum of vantasselite over the $800-1400 \mathrm{~cm}^{-1}$ spectral range is shown in Fig. 4a. A number of intense Raman bands are observed at 1013, 1027 and $1051 \mathrm{~cm}^{-1}$. The first band is assigned to the $\mathrm{PO}_{4}^{3-} v_{1}$ symmetric stretching mode. A strong shoulder band is noted at $1027 \mathrm{~cm}^{-1}$ and is also assigned to this vibrational mode. The observation of multiple symmetric stretching modes supports the concept of non-equivalent phosphate units in the structure of vantasselite. The Raman bands at 1051, 1076 and $1090 \mathrm{~cm}^{-1}$ are attributed to the $\mathrm{PO}_{4}^{3-} v_{3}$ antisymmetric 

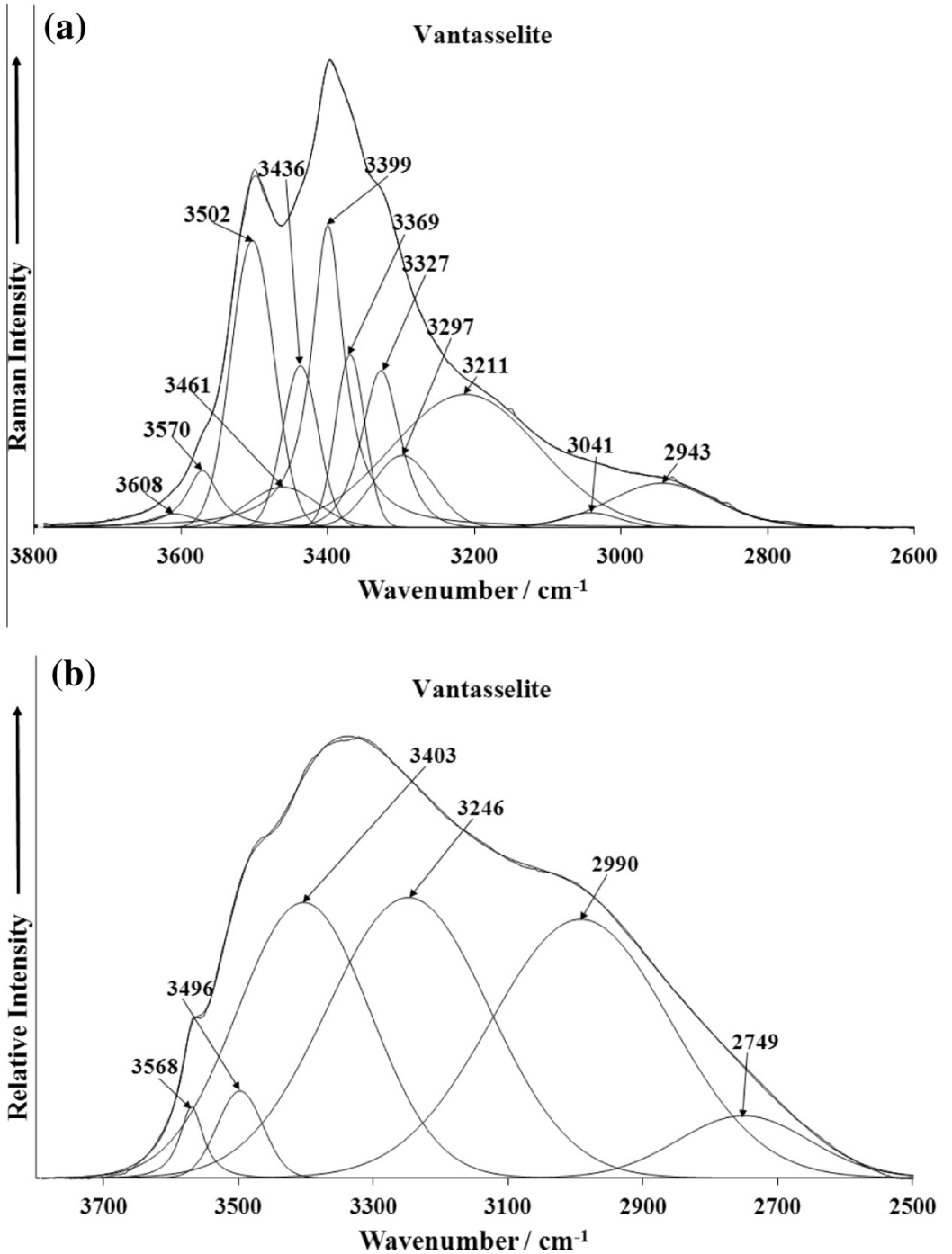

Fig. 6. (a) Raman spectrum of vantasselite (upper spectrum) in the $2600-3800 \mathrm{~cm}^{-1}$ spectral range and (b) infrared spectrum of vantasselite (lower spectrum) in the 2500 $3800 \mathrm{~cm}^{-1}$ spectral range.

stretching vibration. Other lower intensity Raman bands at 1106 , 1128 and $1146 \mathrm{~cm}^{-1}$ may also be also assigned to this vibration. The multiplicity of the Raman bands supports the concept of a reduction in symmetry of the phosphate units. It is possible that some of these bands are due to the PO stretching vibrations of $\mathrm{HOPO}_{3}^{2-}$ units. The two Raman bands at 930 and $949 \mathrm{~cm}^{-1}$ are assigned to $\mathrm{AlOH}$ deformation modes. The low intensity Raman bands at 813 and $833 \mathrm{~cm}^{-1}$ are assigned to water librational modes. A Raman spectrum of vantasselite is given in the RRUFF data base. Sharp Raman bands are noted at 1009, 1051 and $1090 \mathrm{~cm}^{-1}$ which are in agreement with this work. The spectrum looks identical with our spectrum.

Breitinger et al. [6] assigned the band at $999 \mathrm{~cm}^{-1}$ for wardite to $\mathrm{AlOH}$ deformation modes. It is possible that the strong Raman bands for vantasselite at $1051 \mathrm{~cm}^{-1}$ is due to $\delta \mathrm{Al}_{2} \mathrm{OH}$ deformation modes. In our work on the spectroscopy of wardite, the band at $995 \mathrm{~cm}^{-1}$ is very sharp and well resolved. The band at $1051 \mathrm{~cm}^{-1}$ is ever so slightly asymmetric on the low wavenumber side and a component may be resolved at $1045 \mathrm{~cm}^{-1}$. A group of low intensity bands are observed at 1084, 1108, 1120, 1140 and $1186 \mathrm{~cm}^{-1}$ assigned to the $v_{3} \mathrm{PO}_{4}^{3-}$ antisymmetric stretching modes. Breitinger et al. [6] did not report any bands in these positions in the Raman spectrum. They reported infrared bands at 1058 (strong) with shoulders at 1129 and $1168 \mathrm{~cm}^{-1}$ and assigned these bands to $\delta \mathrm{Al}_{2} \mathrm{OH}$ deformation modes. A low intensity broad band at $884 \mathrm{~cm}^{-1}$ is assigned to a water librational mode. In the work of Breitinger et al. a broad low intensity band was found at around $800 \mathrm{~cm}^{-1}$ and was attributed to water librational modes.

The infrared spectrum of vantasselite over the $650-1250 \mathrm{~cm}^{-1}$ spectral range is shown in Fig. $4 \mathrm{~b}$. The spectrum is complex with a number of overlapping bands which may be resolved into component bands. The broadish infrared band at $984 \mathrm{~cm}^{-1}$ assigned to the $\mathrm{PO}_{4}^{3-} v_{1}$ symmetric stretching mode and is the equivalent of the Raman band at $1013 \mathrm{~cm}^{-1}$. The infrared band at $1009 \mathrm{~cm}^{-1}$ may also be ascribed to this vibration. The strong infrared bands at 1044,1078, 1092,1112, 1133, 1180 and $1210 \mathrm{~cm}^{-1}$ are attributed to the $\mathrm{PO}_{4}^{3-} v_{3}$ antisymmetric stretching mode. The infrared spectra of wardite also show a great deal more complexity than the Raman spectra of wardite. The band for wardite at around $994 \mathrm{~cm}^{-1}$ is attributed to the $v_{1} \mathrm{PO}_{4}^{3-}$ symmetric stretching mode. The cluster of bands at 1039, 1056, 1069, 1084, 1102, 1135 and $1165 \mathrm{~cm}^{-1}$ are attributed to the $v_{3} \mathrm{PO}_{4}^{3-}$ antisymmetric stretching modes. Some of these bands may also be due to the $\delta \mathrm{Al}_{2} \mathrm{OH}$ deformation modes, in harmony with the assignment of Breitinger et al. [6]. He and his co-workers stated that the deceptively simple strong IR band centered at $1059 \mathrm{~cm}^{-1}$ for wardite contains at least 
(a)
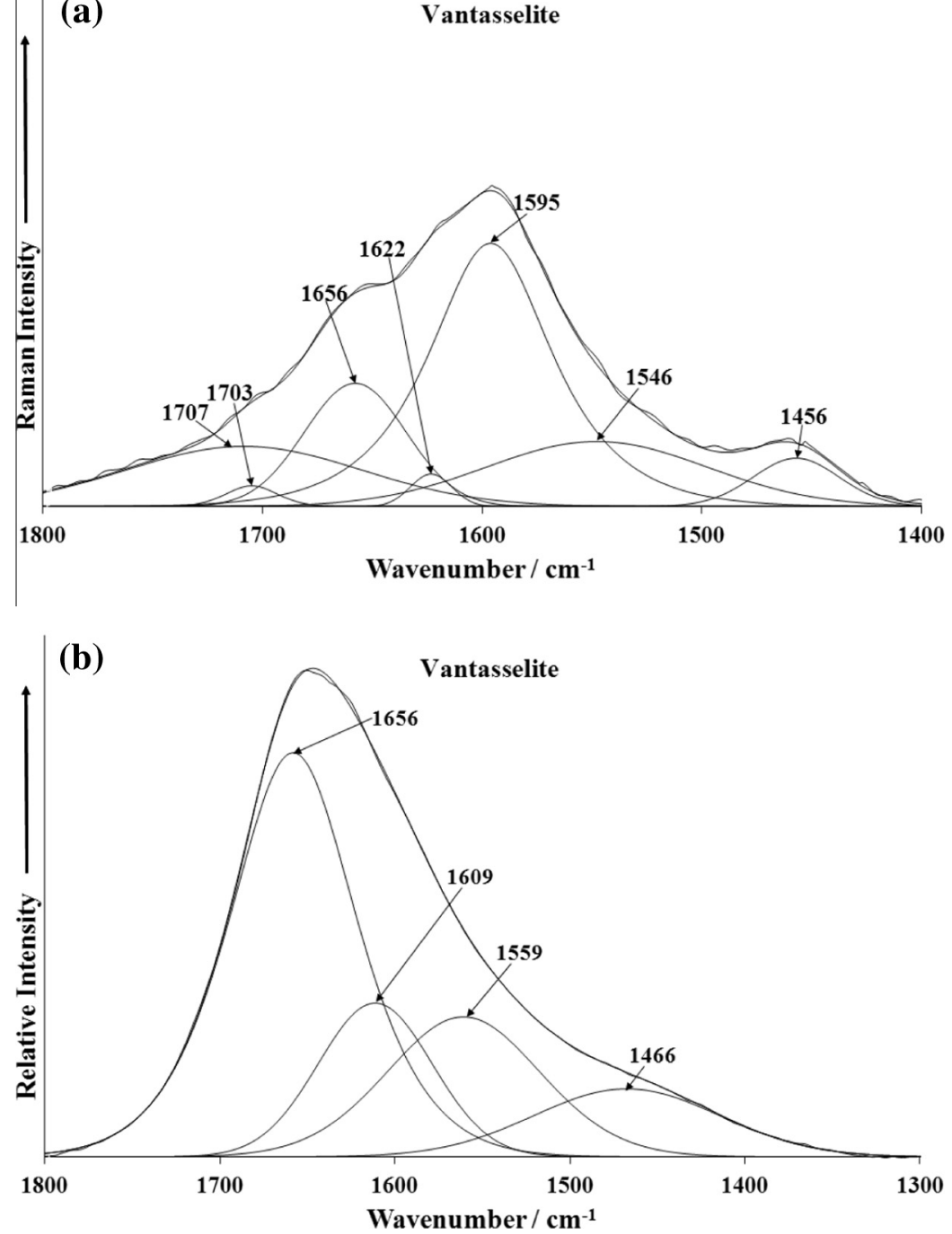

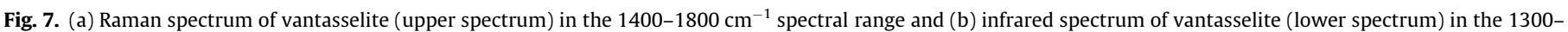
$1800 \mathrm{~cm}^{-1}$ spectral range.

four components of $v\left(\mathrm{PO}_{4}\right)$ generated by lifting of the originally threefold degeneracy of $v_{3}\left(\mathrm{PO}_{4}\right)$ and activation of $v_{1}\left(\mathrm{PO}_{4}\right)$ due to the general position of $\mathrm{PO}_{4}$ and again at least four components of the deformation modes $\delta\left(\mathrm{Al}_{2} \mathrm{OH}\right)$ involving the two pairs of the non-equivalent $\mathrm{OH}$ groups [6]. It is likely that same conclusions may be drawn for the spectra of vantasselite.

The Raman spectrum of vantasselite over the $300-800 \mathrm{~cm}^{-1}$ spectral range is reported in Fig. 5a. The strong Raman bands at $557,593,636$ and $649 \mathrm{~cm}^{-1}$ are assigned to the $v_{4}$ out of plane bending modes of the $\mathrm{PO}_{4}^{3-}$ and $\mathrm{HOPO}_{3}^{2-}$ units. Raman bands are found in the RRUFF spectrum at 491, 515, 555, 596 and $651 \mathrm{~cm}^{-1}$. Raman bands for wardite are observed at 605 and $618 \mathrm{~cm}^{-1}$ with shoulders at 578 and $589 \mathrm{~cm}^{-1}$ and are assigned to the $v_{4}$ out of plane bending modes of the $\mathrm{PO}_{4}^{3-}$ and $\mathrm{HOPO}_{3}^{2-}$ units. Breitinger et al. [6] assigned these bands to $v\left(\mathrm{Al}(\mathrm{O} / \mathrm{OH})_{6}\right)$ stretching vibrations. No phosphate bending modes in the work of Breitinger et al. on the studies of wardite including synthetic wardites were reported. The Raman spectrum of crystalline $\mathrm{NaH}_{2} \mathrm{PO}_{4}$ shows Raman bands at 526, 546 and $618 \mathrm{~cm}^{-1}$ (data obtained by the authors). The Raman bands at 423, 437, 451 and $494 \mathrm{~cm}^{-1}$ are assigned to the $v_{2} \mathrm{PO}_{4}^{3-}$ and $\mathrm{H}_{2} \mathrm{PO}_{4}$ bending modes. A series of bands for wardite are observed at 396, 416, 444, 464 and $489 \mathrm{~cm}^{-1}$ and are attributed to the $v_{2} \mathrm{PO}_{4}^{3-}$ and $\mathrm{H}_{2} \mathrm{PO}_{4}$ bending modes. The Raman spectrum of $\mathrm{NaH}_{2} \mathrm{PO}_{4}$ shows Raman bands at 460 and $482 \mathrm{~cm}^{-1}$. Thus, the series of Raman bands for wardite at $388,400,455,478$ and $502 \mathrm{~cm}^{-1}$ are attributed to the $v_{2} \mathrm{PO}_{4}^{3-}$ bending modes. Raman bands at 317,446 and $515 \mathrm{~cm}^{-1}$ reported by Breitinger et al. for wardite were assigned to vibrational modes of the $\mathrm{AlO}_{6} / \mathrm{AlOH}_{6}$ units. In the infrared spectrum of wardite, a series of bands are observed at 620,643 and $673 \mathrm{~cm}^{-1}$. These bands are attributed to the $v_{4}$ out of plane bending modes of the $\mathrm{PO}_{4}^{3-}$ units. Breitinger et al. assigned bands in this region to $v(\mathrm{Al}(\mathrm{O} /$ $\mathrm{OH})_{6}$ ) stretching vibrations. In harmony with Breitinger et al. [6] assignments, the infrared bands observed at 732, 795 and $893 \mathrm{~cm}^{-1}$ are attributed to water librational modes. Infrared bands are observed at 573,578 and $588 \mathrm{~cm}^{-1}$ are attributed to $\gamma\left(\mathrm{Al}_{2} \mathrm{OH}\right)$ vibrations. The Raman spectrum of vantasselite over the $100-$ $300 \mathrm{~cm}^{-1}$ spectral range is shown in Fig. 5b. Raman bands are observed at 111,153, 209, 227 and $242 \mathrm{~cm}^{-1}$ with bands of lower intensity at 121,162,173,201, 259 and $289 \mathrm{~cm}^{-1}$. These bands are simply described as lattice vibrations.

The Raman spectrum of vantasselite over the $2600-3800 \mathrm{~cm}^{-1}$ spectral range is shown in Fig. 6a. Strong Raman bands are observed at 3211, 3297, 3327, 3369, 3399, 3436, $\mathrm{cm}^{-1}$ and are assigned to water stretching vibrations. The Raman band at $3502 \mathrm{~cm}^{-1}$ is assigned to the $\mathrm{AlOH}$ stretching vibration. The 
infrared spectrum of vantasselite over the $2500-3800 \mathrm{~cm}^{-1} \mathrm{spec}-$ tral range is shown in Fig. $6 \mathrm{~b}$. The spectrum is broad with a series of overlapping bands observed at 2749, 2990, 3246, 3403, 3496 and $3568 \mathrm{~cm}^{-1}$. This latter band is assigned to the stretching vibration of $\mathrm{OH}$ units while the remainder of the bands is assigned to water stretching vibrations. The position of the water stretching vibration provides evidence for strong hydrogen bonding and that water is involved in different hydrogen bonding arrangements. Sharp infrared bands for wardite are observed at 3544 and $3611 \mathrm{~cm}^{-1}$ and are attributed to the $\mathrm{OH}$ stretching vibrations of the hydroxyl units. Two shoulder bands are observed at 3532 and $3601 \mathrm{~cm}^{-1}$ are also assigned to the $\mathrm{OH}$ stretching vibrations. Breitinger et al. [6] found infrared bands at 3520 (vw), 3545 (s), 3585 (sh) and $3613 \mathrm{~cm}^{-1}(\mathrm{~m})$. Breitinger et al. [6] states that the $v(\mathrm{OH})$ modes in the two independent pairs of symmetry-correlated $\mathrm{OH}$ groups classify as $2 a+2 b$; with the correlation splitting between $a$ and $b$ species depending on the distances in each of the pairs [6]. The $v(\mathrm{OH})$ region of IR spectra of wardite shows two sharp bands ( 3613 and $3545 \mathrm{~cm}^{-1}$ ) with two weak shoulders or satellites ( 3580 and $3520 \mathrm{~cm}^{-1}$ ). It is likely that the two sharp infrared bands are due to two independent and non-equivalent $\mathrm{OH}$ units. The two sharp shoulder bands may be attributed to the Al-OH-Fe groups.

The Raman spectrum of vantasselite over the $1400-1800 \mathrm{~cm}^{-1}$ spectral range is shown in Fig. 7a. The spectral profile is broad. Raman bands are noted at $1595,1622,1656 \mathrm{~cm}^{-1}$ and these bands are ascribed to water bending modes. The number of bands observed in this spectral region is in harmony with the number of bands observed in the water stretching region. The infrared spectrum of vantasselite over the $1300-1800 \mathrm{~cm}^{-1}$ spectral range is shown in Fig. 7b. Infrared bands are observed at 1609 and $1656 \mathrm{~cm}^{-1}$ and are ascribed to water bending vibrations.

\section{Conclusions}

We have studied a sample of the phosphate mineral vantasselite from the Bihain, Vielsalm, Stavelot Massif, Luxembourg Province, Belgium. The chemical characterization via SEM/EDS shows a homogeneous phase, composed of $\mathrm{Al}$ and $\mathrm{P}$. The SEM image of vantasselite sample shows a cleavage fragment with tabular habitus.

Vantasselite is one of many aluminum phosphate minerals, including wardite, wavellite, variscite and augelite. The mineral can be successfully analyzed by Raman spectroscopy and a comparison of the Raman spectrum made with that of wardite and augelite. The Raman spectrum is dominated by an intense band at $1029 \mathrm{~cm}^{-1}$ assigned to the $\mathrm{PO}_{4}^{3-} v_{1}$ symmetric stretching mode. Raman bands at 545, 559, 581, 616 and $635 \mathrm{~cm}^{-1}$ are assigned to the $v_{4} \mathrm{PO}_{4}^{3-}$ bending modes. The Raman bands at 417, 444, 462, 477 and $480 \mathrm{~cm}^{-1}$ are due to the $v_{2} \mathrm{PO}_{4}^{3-}$ bending modes. The observation of multiple bending modes offers strong support for the reduction in symmetry of the phosphate anion in the vantasselite structure. Strong Raman bands are observed at 3211, 3297, $3327,3369,3399,3436, \mathrm{~cm}^{-1}$ and are assigned to water stretching vibrations. The Raman band at $3502 \mathrm{~cm}^{-1}$ is assigned to the $\mathrm{AlOH}$ stretching vibration. Vibrational spectroscopy offers a unique means of studying the molecular structure of vantasselite.

\section{Acknowledgments}

The financial and infra-structure support of the Discipline of Nanotechnology and Molecular Science, Science and Engineering Faculty of the Queensland University of Technology, is gratefully acknowledged. The Australian Research Council (ARC) is thanked for funding the instrumentation. The authors would like to acknowledge the Center of Microscopy at the Universidade Federal de Minas Gerais (http://www.microscopia.ufmg.br) for providing the equipment and technical support for experiments involving electron microscopy. $\mathrm{R}$. Scholz thanks to $\mathrm{CNPq}-$ Conselho Nacional de Desenvolvimento Científico e Tecnológico (Grant Nos. 306287/2012-9 and 402852/2012-5).

\section{Appendix A. Supplementary data}

Supplementary data associated with this article can be found, in the online version, at http://dx.doi.org/10.1016/j.saa.2015.03.090.

\section{References}

[1] A.M. Fransolet, Bull. Min. 110 (1987) 647-656.

[2] V.C. Farmer, Mineralogical Society Monograph 4: The Infrared Spectra of Minerals, 1974.

[3] R.L. Frost, W. Martens, P.A. Williams, J.T. Kloprogge, Min. Mag. 66 (2002) $1063-$ 1073.

[4] R.L. Frost, W.N. Martens, T. Kloprogge, P.A. Williams, Neues Jahrb. Min. Mt. (2002) 481-496.

[5] R.L. Frost, P.A. Williams, W. Martens, J.T. Kloprogge, P. Leverett, J. Raman Spectrosc. 33 (2002) 260-263.

[6] D.K. Breitinger, H.H. Belz, L. Hajba, V. Komlosi, J. Mink, G. Brehm, D. Colognesi, S.F. Parker, R.G. Schwab, J. Mol. Struct. 706 (2004) 95-99.

[7] P. Tarte, A.M. Fransolet, F. Pillard, Bull. Min. 107 (1984) 745-754.

[8] R.L. Frost, Y. Xi, R. Scholz, Spectrochim. Acta A108 (2013) 244-250.

[9] A.N. Lazarev, Nauka, Leningrad, 1968.

[10] W. Jastrzebski, M. Sitarz, M. Rokita, K. Bulat, Spectrochim. Acta A79 (2011) $722-727$.

[11] I. Petrov, B. Soptrajanov, N. Fuson, Zeit. Anorgan. Allgemeine Chem. 358 (1968) $178-186$.

[12] I. Petrov, B. Soptrajanov, N. Fuson, J.R. Lawson, Spectrochim. Acta A23 (1967) 2637-2646.

[13] K.I. Petrov, I.V. Tananaev, V.G. Pervykh, S.M. Petushkova, Zh. Neorganicheskoi Khim. 12 (1967) 2645-2650.

[14] J. Cejka, J. Sejkora, S. Bahfenne, S.J. Palmer, J. Plasil, R.L. Frost, J. Raman Spectrosc. 42 (2011) 214-218.

[15] R.L. Frost, S. Bahfenne, J. Raman Spectrosc. 42 (2011) 219-223.

[16] R.L. Frost, S. Bahfenne, J. Cejka, J. Sejkora, J. Plasil, S.J. Palmer, E.C. Keeffe, I. Nemec, J. Raman Spectrosc. 42 (2011) 56-61.

[17] R.L. Frost, S.J. Palmer, J. Mol. Struct. 988 (2011) 47-51.

[18] R.L. Frost, S.J. Palmer, H.J. Spratt, W.N. Martens, J. Mol. Struct. 988 (2011) $52-$ 58.

[19] S.J. Palmer, R.L. Frost, J. Raman Spectrosc. 42 (2011) 224-229.

[20] L.H. Coelho, L. Fonseca, K.M. Kaneko, J.C.A. Melo, II Simp. Bras. Minério de Ferro, ABM, Ouro Preto, 1999. pp. 44-52.

[21] R.L. Frost, T. Kloprogge, P.A. Williams, W. Martens, T.E. Johnson, P. Leverett, Spectrochim. Acta A58 (2002) 2861-2868.

[22] R.L. Frost, Spectrochim. Acta A60 (2004) 1439-1445.

[23] R.L. Frost, M.L. Weier, K.L. Erickson, O. Carmody, S.J. Mills, J. Raman Spectrosc. 35 (2004) 1047-1055. 